\title{
Emergence pattern and spatial distribution of the common cockle Cerastoderma edule
}

\author{
C. A. Richardson, I. Ibarrola*, R. J. Ingham \\ School of Ocean Sciences, University of Wales, Bangor, Marine Science Laboratories, Menai Bridge, Anglesey LL59 5EY, \\ United Kingdom
}

\begin{abstract}
When groups of freshly collected cockles Cerastoderma edule L. were transferred to laboratory conditions and exposed to cycles of tidal emersion and immersion and a light regime of $12 \mathrm{~h}$ light: $12 \mathrm{~h}$ dark, up to $40 \%$ of the group emerged onto the surface of the substratum during emersion at the onset of darkness. This pattern of emergence decreased in intensity from $37 \%$ to $10 \%$ of all individuals emerging after $30 \mathrm{~d}$ in the laboratory. However, not all the same cockles emerged each day. After emergence, the cockles remained quiescent until immersion, when they actively roamed and ploughed across the sand surface and then reburrowed. During movement the cockles produced furrows up to $0.5 \mathrm{~m}$ in length; at high densities collisions with other buried cockles occasionally occurred, which in turn stimulated emergence and a change of position. Groups of cockles previously exposed to a tidal cycle and light:dark regime responded to continuous darkness by emerging onto the substratum for 3 low tides before the activity pattern disappeared. The intensity of the emergence pattern in continuous darkness was less than the nocturnal activity observed during light : dark conditions. Similarly, under continuous immersion, emergence during darkness was less pronounced than under simulated tidal emersion. In continuous illumination an emergence pattern was absent. The nocturnal pattern of emergence observed in the laboratory can be explained in terms of the cockles' reaction to burial with sediment. In laboratory experiments, cockles which were buried with a covering of sediment at the onset of emersion responded immediately by emerging onto the sediment surface. One group maintained in continuous darkness emerged at low water and continued to roam and plough across the surface when they were immersed, whereas a second group subjected to continuous illumination emerged upon burial and then reburrowed. Similar experiments carried out in the natural environment confirmed the biological significance of the laboratory-induced emergence rhythm. On the shore, replicate areas were covered with sediment during daylight, just prior to emersion of the natural cockle beds. Approximately $1.5 \mathrm{~h}$ after burial, cockles were observed to emerge with peak activity at the onset of darkness, and again $24 \mathrm{~h}$ later. However, cockles did not emerge in any numbers in control areas in which no sediment was added. The sudden burial of cockles with sediment during a storm will stimulate them to move in order to maintain contact with the sand surface for feeding and respiration. The disturbance of cockles during collection and the sudden onset of darkness in the laboratory followed by the immediate emergence of the cockles, simulated the cockles' reaction to deposition of sediment in the field. The observed crawling and burrowing behaviour of the cockles during high tide and darkness represents a situation in which the cockle is continuing to try to emerge as if it was still covered in sediment.
\end{abstract}

\section{INTRODUCTION}

Burrowing behaviour in bivalves and the mechanism involved in the burrowing process have been described in detail by Trueman et al. (1966) and True-

\footnotetext{
- Present address: Departamento de Biologia Animal y Genetica, Facultad de Ciencieas, Apartado 644 48080, Bilbao, Spain
}

man (1983). Some of the environmental factors known to influence burrowing activity are wave action (Breum 1970), temperature (McLachlan \& Young 1982), substratum type and shell shape (Trueman et al. 1966; for review see Stanley 1987) and parasite infection (Swennen 1969, Hulscher 1973). In addition to burrowing into the sediment some bivalves, particularly species belonging to the family Cardidae, have been observed to crawl over consolidated surfaces 
(Stanley 1970, Rygg 1970), whilst other species like the spiny cockle Acanthocardia aculeata even show leaping activity as an escape response to the presence of predatory starfish (Ansell 1968).

Cockles Cerastoderma edule L. (Orton 1926, Kreger 1940) and clams Tapes pullastra (Quayle 1949) have been observed to move over the substratum in both the natural environment and in laboratory aquaria. Although the significance of the movements of these filter feeding bivalves is unclear, it has been shown that the movement of some deposit feeding bivalve species is related to their dispersion and distribution, and to the maintenance of feeding territories (Holme 1950, Levinton 1972, Wilson 1976, Wilson \& Shelley 1986). Other bivalves, like the surf clams Donax spp., display a high degree of burrowing activity and undergo tidal migrations in the swash zone of the flood and ebb tide on exposed sandy shores (Ansell \& Trevallion 1969, Brown 1983, McLachlan 1988). The ability to move in or on the surface of the substratum must be an important factor in the maintenance and structuring of bivalve populations in unstable and changing intertidal environments.

In this study, an observation that Cerastoderma edule maintained in laboratory tanks would emerge from the sediment and move across the surface only during periods of darkness was investigated and the significance of these movements in maintaining the structure of the population is discussed.

\section{MATERIALS AND METHODS}

Samples of cockles Cerastoderma edule (shell height 12 to $27 \mathrm{~mm}$ ) were collected between September 1990 and March 1991, September and October 1991, and October and December 1992 from a position just below mean tide level (MTL) from a sandy shore at Traeth Melynog, Aber Menai Point, at the eastern end of the Menai Strait, North Wales, UK. Freshly collected cockles were immediately transferred to the laboratory, where they were maintained in one of 2 experimental regimes. In a first series of experiments, conducted between September 1990 and March 1991, cockles were placed in 2 aquaria $(56 \times 36 \times 20 \mathrm{~cm})$ containing, to a depth of $10 \mathrm{~cm}$, natural sediment collected from the nearby Newborough Beach, and supplied with running seawater which was vigorously aerated. In this series of experiments the inflow and outflow of seawater into the tanks were controlled manually with a tap to provide a tidal cycle of approximately $6 \mathrm{~h}$ immersion and $6 \mathrm{~h}$ emersion. Immersion and emersion were almost instantaneous due to the small size of the experimental tank. In a second series of experiments, conducted during September and October 1991 and
1992, cockles were placed in a large tank $(140 \times 55 \times$ $20 \mathrm{~cm}$ ) containing in separate halves of the tank, to a depth of $10 \mathrm{~cm}$, Newborough sand and undisturbed sediment from Traeth Melynog. The inflow and outflow of water were controlled automatically by solenoid valves providing a tidal cycle of either $8 \mathrm{~h}$ immersion and $4 \mathrm{~h}$ emersion (in 1991) or $2.5 \mathrm{~h}$ emersion and $9.5 \mathrm{~h}$ immersion (in 1992). These tidal regimes were chosen because they corresponded approximately to the regime of immersion and emersion experienced naturally by the cockles at Traeth Melynog, and also for convenience, as other tidal tank systems used in another experiment were regulated by the same controller. In these tank experiments the 'flood' and 'ebb' tides flowed across the sand surface realistically simulating the natural situation. A final depth of $10 \mathrm{~cm}$ of water above the buried cockles was achieved. In both series of experiments the cockles were exposed to a $12 \mathrm{~h}$ light : $12 \mathrm{~h}$ dark regime of illumination, similar to the natural cycle of illumination experienced in February and March. The cockles were occasionally fed microalgal supplements of Tetraselmis chuii.

In both experiments the number of cockles appearing and/or moving on the surface of the sediment were counted every $30 \mathrm{~min}$. Cockles were considered to be on the surface when more than half of the 2 shell valves and the umbo were visible. The emergence of the umbo was indicative of the start of a period of migration.

To supplement the visual observations of the cockles' behaviour during emersion and immersion, continuous time lapse video recordings using an infrared camera and light source were made during both light and dark periods. Due to the narrow field of view of the camera lens, only one third of the sand surface could be monitored. However, the video recordings provided more detail on the appearance, movement and interactions of individual cockles to supplement the data obtained by the half-hourly visual observations.

A series of laboratory experiments using different environmental regimes was undertaken to assess the effect of (1) illumination and darkness, (2) the timing of darkness in relation to emersion and immersion. (3) continuous immersion, (4) the presence or absence of microalgal food, (5) substratrum type, (6) the frequency of appearance of individuals, (7) the distribution patterns, and ( 8 ) burial by sediment, on the behaviour of the cockles. Where appropriate, a paired $t$-test or Mann-Whitney test was performed on the data to determine any differences in the emergence activity under different conditions.

In order to determine the dispersion patterns of the cockles at the end of the experiments, the centre of each buried cockle was marked during emersion with a small wooden marker pushed into the sand. The dis- 
tance between each cockle and its respective neighbours was measured horizontally using vernier calipers. Nearest neighbour analysis (Clark \& Evans 1954, Wilson 1976) was used to ascertain the dispersion patterns of the cockles in the tanks. The cockles were considered to be aggregated when $R$ (a measure of the degree of departure from randomness), was significantly $<1.0$ and uniformly distributed when $R>1.0$.

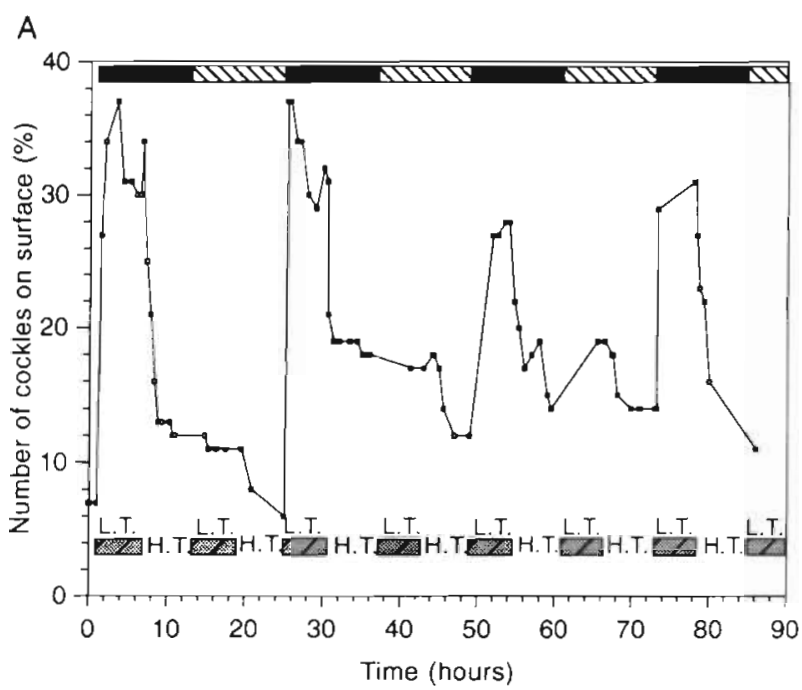

B

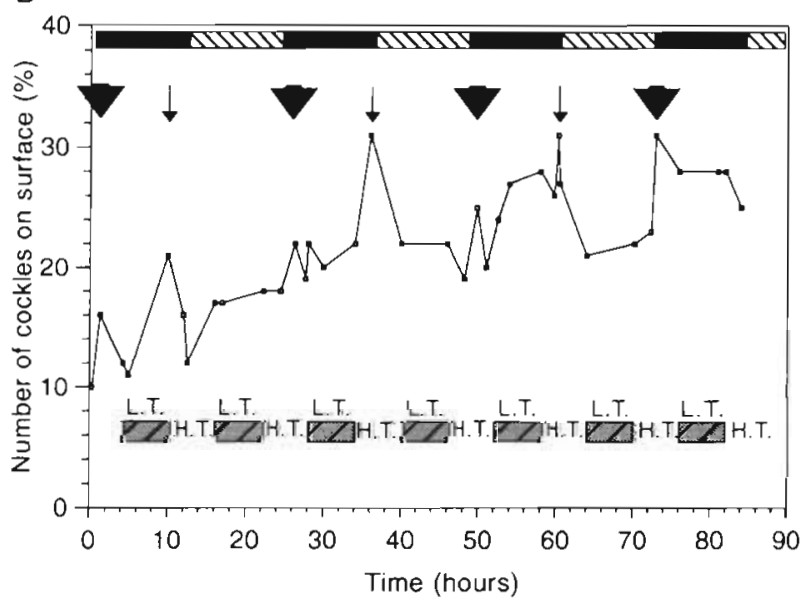

Darkness $\Delta \nabla \nabla$ Light

Fig. 1. Cerastoderma edule. Four-day records of emergence behaviour in 100 cockles maintained in a simulated semidiurnal tidal regime in the laboratory. HT = high tide; LT = low tide. (A) Emergence behaviour in $12 \mathrm{~h}$ light: $12 \mathrm{~h}$ dark. The period of darkness coincides with emersion. (B) Emergence behaviour in $12 \mathrm{~h}$ light : $12 \mathrm{~h}$ dark in which the period of darkness occurs during immersion at 'high tide'. Two peaks of activity can be seen during each $24 \mathrm{~h}$ period: one close to the times of onset of darkness midway during 'high tide' (large arrows) and the other close to the times of the immersion periods immediately following the 'low tide' in darkness (small arrows)
For comparison, observations of the distribution and behaviour of the cockle population at Traeth Melynog during various states of the tide and at different times of the day and night were made. The dispersion pattern of the cockles at Traeth Melynog was determined at 3 tidal levels between high and low water of neap tides. The use of nearest neighbour analysis to study the dispersion pattern in the natural population is inappropriate because of the difficulty of marking and measuring the distance between many hundreds of cockles. Instead, the dispersion pattern was determined by the $x^{2}$ approximation to the Fisher Coefficient of Dispersion (Holme 1950, Clark \& Milne 1955). The coefficient of dispersion was calculated from counts of the number of cockles in $25 \times 0.04 \mathrm{~m}^{2}$ quadrats taken from within an area of $1 \mathrm{~m}^{2}$.

The shore at Traeth Melynog was visited on several occasions when darkness and low tide coincided to investigate whether emergence occurred naturally at darkness. The onset of darkness was also simulated in the field by placing large $(3 \times 3 \mathrm{~m})$ black plastic sheets over the sediment surface.

The behaviour of cockles buried experimentally with sediment was studied on the shore. Five areas of $1 \mathrm{~m}^{2}$, in a $100 \mathrm{~m}^{2}$ area, were randomly selected at MTL and marked with stakes. Three areas were covered with sieved sand to a depth of $2 \mathrm{~cm}$ during daylight whilst the cockles were still immersed by $20 \mathrm{~cm}$ of water. Two control areas were left undisturbed. The number of cockles appearing on the surface was noted during daylight and darkness at low tide. On the shore adjacent to the experimental areas, cockle density was determined in replicate quadrats and the average density per $\mathrm{m}^{2}$ determined. Any emerging cockles were expressed as a percentage of this density.

\section{RESULTS}

\section{Laboratory experiments}

\section{Effects of illumination, darkness, emersion and immersion on behaviour}

The onset of darkness in the laboratory stimulated the cockles to appear on the surface of the sediment in the tanks. Fig. 1A illustrates the percentage of cockles on the surface during $4 \mathrm{~d}$ of a $30 \mathrm{~d}$ monitoring period in which 100 cockles were maintained in a simulated semidiurnal tidal regime and $12 \mathrm{~h}$ light: $12 \mathrm{~h}$ dark, where the onset of darkness coincided with emersion. Visual observations and time lapse video recordings showed that the initial appearance of the cockles was coincident with the sudden onset of darkness. The first cockle was usually visible 
and completely exposed on the surface within $1 \mathrm{~min}$ of darkness and for a further 20 min the cockles continued to remain active. After this period of activity, which involved probing movements of the foot and shell gaping, there was no further movement until immersion. From an analysis of $7 \mathrm{~d}$ video recording, the average time for the first cockle to become completely exposed and the maximum period for emergence were calculated as $1.2 \pm 0.5 \mathrm{~min}$ and $16.3 \pm 6.0 \mathrm{~min}$ respectively. Once the cockles became immersed by the flooding tide, the numbers on the surface decreased within the first $2 \mathrm{~h}$ as they moved randomly across the surface and reburrowed in a new location. Time lapse video recordings showed that the cockles often 'ploughed' across the surface of the sediment, forming long furrows, (some $>0.5 \mathrm{~m}$ in length) which were clearly visible during the light period. During $30 \mathrm{~d}$ observations (Fig. 2), the number of emerging cockles decreased from a maximum of $37 \%$ on Day 5 to $10 \%$ on Day 27. For comparison, the times of full and new moon have been indicated in the figure. Although there is possibly a spring-neap Iunar cycle, the observations are too few for significance, especially with the variability of the response during the new moon and the absence of data for $3 \mathrm{~d}$ during 7 to 9 February. Similar patterns of behaviour in other experiments suggests it is unlikely. These experiments were repeated with different densities of cockles (100, $50,25,10$ ) on 4 other occasions and similar results

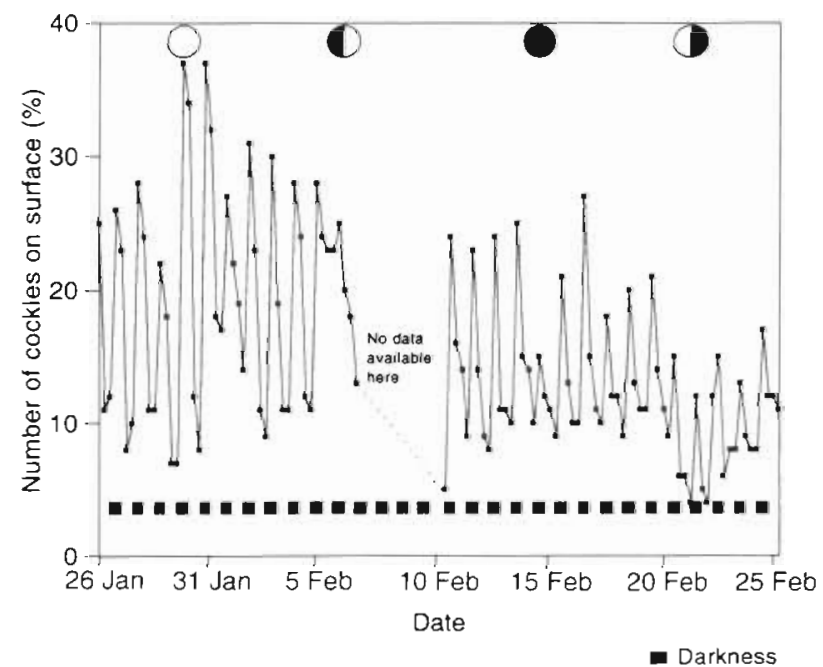

Fig. 2. Cerastoderma edule. A $30 \mathrm{~d}$ record of emergence behaviour in 100 cockles kept under simulated conditions of tidal emersion and $12 \mathrm{~h}$ light: $12 \mathrm{~h}$ darkness. Daily periods of darkness are indicated by small black squares at the bottom of the figure. Activity decreased from $37 \%$ on Day 5 to $10 \%$ on Day 27 Times of new and full moon are indicated at the top of the figure, and although there is a suggestion of a possible spring-neap lunar cycle, the observations are too few for significance were obtained, the rhythm of emergence slowly disappearing with time

The behaviour of cockles over a $4 \mathrm{~d}$ period whilst maintained in the simulated tidal regime, where the onset of darkness occurred during the high tide period, is shown in Fig. 1B. Overall, the percentage emergence was lower than that observed when emersion coincided exactly with the onset of darkness. Peaks of emergence activity can be seen more or less coincident with either the onset of darkness (large arrows), mid way through high tide, or the immersion period immediately following low tide in darkness (small arrows). On 3 out of the 4 occasions there was also an increase $(10 \%)$ in the number of cockles appearing on the surface during darkness and low tide.

Fig. 3A shows the emergence activity of cockles maintained in the tidal regime and subjected first to a $12 \mathrm{~h}$ light: $12 \mathrm{~h}$ dark regime and then to continuous darkness. The cockles showed the usual pattern of noctural emergence prior to the period of continuous darkness. Thereafter, the cockles emerged onto the substratum for only 3 low tides. By the 4 th low tide the rhythm of activity had disappeared. However, the instensity of emergence was less pronounced than the noctural activity observed during light and dark conditions and even during the usual noctural period there was not the decrease in activity experienced earlier. This is not an unusual feature, since Fig. $1 \mathrm{~A}$ illustrates that more than $20 \%$ of the cockles may remain on the surface during high tide in the dark.

The behaviour of cockles continuously immersed in a $12 \mathrm{~h}$ light: $12 \mathrm{~h}$ dark regime produced the pattern of emergence shown in Fig. 3B. These cockles had initially been maintained in simulated tidal conditions for some time prior to continous immersion, so their activity was reduced (cf. Fig. 2). At the onset of darkness 15 to $20 \%$ of the cockles appeared on the sand surface. These periods of nocturnal activity persisted for about $2 \mathrm{~h}$ in which the cockles moved across the sand surface and reburrowed. During Day 3 of the experiment, when the light was not switched off during the expected night time, and the cockles experienced a $24 \mathrm{~h}$ period of continuous illumination, no cockles emerged. The reintroduction of darkness again stimulated the cockles to emerge. No significance is attached to the lower reburying level after the second dark period, since this represents a small percentage of cockles and is a normal pattern of activity (cf. Fig. 1).

\section{Frequency of appearance of cockles}

In many of the experiments, the same cockles were observed to appear on the surface on consecutive nights. In order to study whether this behaviour pat- 
A

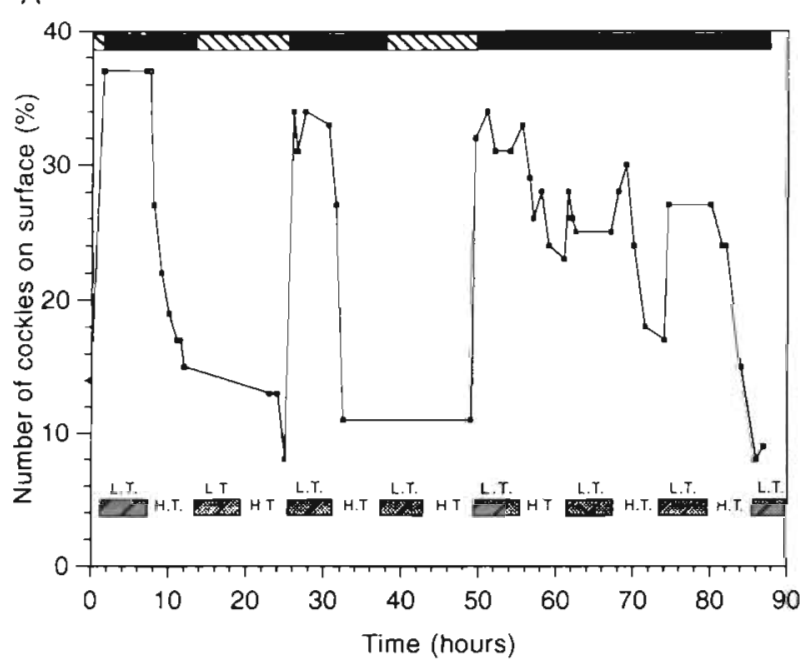

B

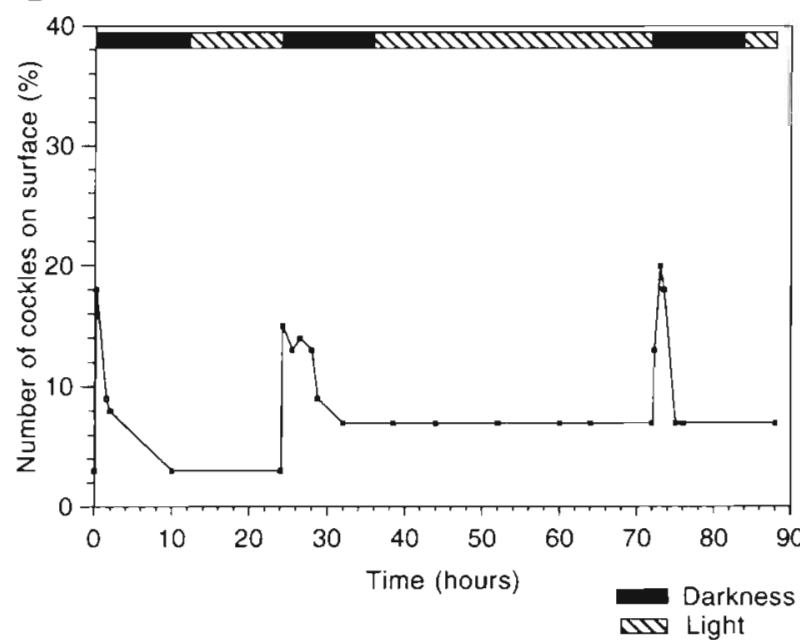

Fig. 3. Cerastoderma edule. Four-day records of emergence behaviour in 100 cockles kept under laboratory conditions. (A) Emergence behaviour in a simulated semidiurnal tidal regime under $12 \mathrm{~h}$ light: $12 \mathrm{~h}$ dark. On Day 3 of the experiment the light was switched off, i.e. the cockles experienced 24 h darkness, and the intensity of the emergence activity decreased during the subsequent 4 'low tides'. HT = high tide; LT $=$ low tide. (B) Emergence behaviour of continuously immersed cockles in $12 \mathrm{~h}$ light : $12 \mathrm{~h}$ dark. A burst of nocturnal activity occurs, beginning at the onset of darkness. During the third day of the experiment the light was not switched off during the expected night time, i.e. the cockles experienced $24 \mathrm{~h}$ light, and no cockles emerged from the substratum. When the light was once again switched off, the cockles briefly emerged

tern was restricted to only a small proportion of the cockles or occured in all cockles in the group, one tank was divided into 15 quadrats (approximately $0.13 \mathrm{~m}^{2}$ ), and 3 cockles of different sizes (range 12 to $27 \mathrm{~mm}$ ) placed in each quadrat. The appearance of individual cockles was monitored for $11 \mathrm{~d}$. The cockles emerged during darkness and emersion, reaching a maximum of $42 \%$ during Day 3 . The observations showed that $75 \%$ of the cockles were active for at least one low tide during the $11 \mathrm{~d}$ experiment. Fifty-nine percent appeared for at least 3 nights, whilst $29 \%, 9 \%$ and $3 \%$ appeared for 6,8 and 11 nights respectively. The larger cockles ( 22 to $27 \mathrm{~mm}$ ) were less active than the smaller ones (12 to $22 \mathrm{~mm}$ ). The large percentage of cockles appearing during low tide in the dark (Figs. 1 \& 3A) therefore consists of individuals that only occasionally migrated across the surface.

In order to eliminate the possible effects of different substratum type and the presence and absence of microalgal food on the activity patterns, the emergence activity of cockles in 2 sediments, Newborough sand and undisturbed sediment from Traeth Melynog, and in fed and unfed conditions were compared. No significant differences $(p<0.05)$ in activity were observed.

\section{Effect of dispersion patterns and density on cockle behaviour}

The observations here showed that when 50 cockles were randomly distributed in a tank (density $200 \mathrm{~m}^{-2}$ ), their activity declined from $20 \%$ to $5 \%$ after $36 \mathrm{~d}$ and they became uniformly distributed. To examine whether the cockles' activity during emersion and darkness might be related to a negative interaction between individuals, cockles were placed into a tidal tank divided into 4 equal compartments $(35 \times 26 \mathrm{~cm})$. Ten, 25, 50 and 100 cockles were placed into each compartment. At the start of the experiment cockles were placed in tight aggregated clumps and nearest neighbour analysis performed. Since the analysis requires measurement of the distance between the centre of the cockle shells, the mean distance between individuals will be equal to their mean size. It will be noted that the coefficient of dispersion $(R)$ for the densely packed cockles (row 4 , Table 1 ) has been calculated as 1.106 which is classified as a random distribution. The reason for this is that the cockles almost completely filled the entire area of the compartment in the tank and, since the area is included in the calculation of $R$, the cockles are randomly distributed, even though they were placed in an aggregated clump.

The number of cockles on the sand surface was recorded throughout the $11 \mathrm{~d}$ experiment. The number appearing at low tide during the dark declined rapidly after the first day in all the tanks except that with the highest density, in accordance with the previous findings (Fig. 2). Nearest neighbour analysis shows (Table 1) that the cockles in the 2 lowest densities (rows 1 and 2) became randomly distributed and the 
Table 1 Cerastoderma edule. Nearest neighbour analysis for 4 densities of cockles at the beginning and at the end of an $11 \mathrm{~d}$ experiment. $R=$ Coefficient of dispersion; $C=$ measure of deviation from the Poisson distribution; $\mathrm{A}=$ aggregated, $\mathrm{R}=\mathrm{random}$, $\mathrm{U}=$ uniform distribution

\begin{tabular}{|c|c|c|c|c|c|c|c|c|c|}
\hline \multirow{2}{*}{$\begin{array}{c}\text { No. of } \\
\text { cockles }\end{array}$} & \multirow{2}{*}{$\begin{array}{l}\text { Cockle } \\
\text { density } \\
\left(\mathrm{m}^{-2}\right)\end{array}$} & \multicolumn{4}{|c|}{ At the beginning of expt } & \multicolumn{4}{|c|}{ At the end of expt } \\
\hline & & $\begin{array}{c}\text { Distance } \\
\text { between cockles } \\
\text { (mm) }\end{array}$ & $R$ & $C$ & Distribution & $\begin{array}{c}\text { Distance } \\
\text { between cockles } \\
(\mathrm{mm})\end{array}$ & $R$ & $C$ & Distribution \\
\hline 10 & 57.72 & 0 & 0.371 & -3.804 & A & 40.5 & 0.987 & 0.077 & $\mathrm{R}$ \\
\hline 25 & 129.87 & 0 & 0.533 & -4.469 & A & 24.3 & 1.086 & 0.825 & $\mathrm{R}$ \\
\hline 50 & 259.74 & 0 & 0.772 & -3.090 & A & 16.8 & 1.313 & 2.294 & $\mathrm{U}$ \\
\hline 100 & 534.76 & 0 & 1.106 & 0.469 & $\mathrm{R}$ & 4.1 & 1.266 & 1.177 & $U$ \\
\hline
\end{tabular}

rhythm of activity disappeared. Although the rhythm of emergence in the cockles in the second highest density (row 3, Table 1) had disappeared by Day 11, these individuals had become uniformly distributed. In the highest density, however, the cockles were still active at the end of the experiment, the mean distance between adjacent cockles had only increased by $4.10 \pm$ $6.77 \mathrm{~mm}$ during the period, and the calculated $R$ value indicated a uniform distribution. Time lapse video recordings of the highest density cockles were made throughout the $11 \mathrm{~d}$ experiment and the movements and interaction of cockles analysed.

\section{Locomotion of cockles on sand surface}

Analysis of the time lapse video recordings showed that the cockles moved randomly across the sand surface with the direction of movement depending entirely on the orientation of the shell when the cockle emerged from the substratum. Observations showed that as the cockles moved across the sand surface and came into contact with other buried cockles they often tried to burrow, and in doing so induced the buried cockles to emerge and also reorientate. Such interactions were common during 'high tide' in both light

Table 2. Cerastoderma edule. Numbers of cockles emerging onto the sediment surface during both low and high tide in the light and dark during a $7 \mathrm{~d}$ period

\begin{tabular}{|ccccc|}
\hline \multirow{2}{*}{ Day no. } & \multicolumn{2}{c}{ Low tide } & \multicolumn{2}{c|}{ High tide } \\
& Darkness & Light & Darkness & Light \\
\hline 1 & 55 & 0 & 40 & 16 \\
2 & 35 & 0 & 27 & 27 \\
3 & 18 & 0 & 43 & 7 \\
4 & 21 & 0 & 29 & 9 \\
5 & 12 & 0 & 14 & 2 \\
6 & 11 & 0 & 15 & 3 \\
7 & 8 & 0 & 7 & 3 \\
\hline
\end{tabular}

and dark conditions under densely packed conditions. Table 2 shows the number of cockles emerging onto the sand surface for $7 \mathrm{~d}$ in the dark and light conditions during 'low tide' (columns II and III respectively) Columns IV and $V$ show the number of positional changes the cockles made during 'high tide', which were significantly higher during darkness than during the light (Mann-Whitney test, $w=69.0, \mathrm{p}<0.041$ ).

During each journey across the sand surface the cockles stopped several times, often changing direction and speed of movement. The average surface speed during darkness at high tide was $8.4 \pm 4.2 \mathrm{~mm} \mathrm{~min}^{-1}(\mathrm{n}=10)$ and was not significantly different $(p<0.38, t=0.90)$ from the speed of movement during the light, $6.6 \pm 4.2$ $\mathrm{mm} \min ^{-1}(\mathrm{n}=10)$. The net gain of movement on the sediment surface was to increase the distance between

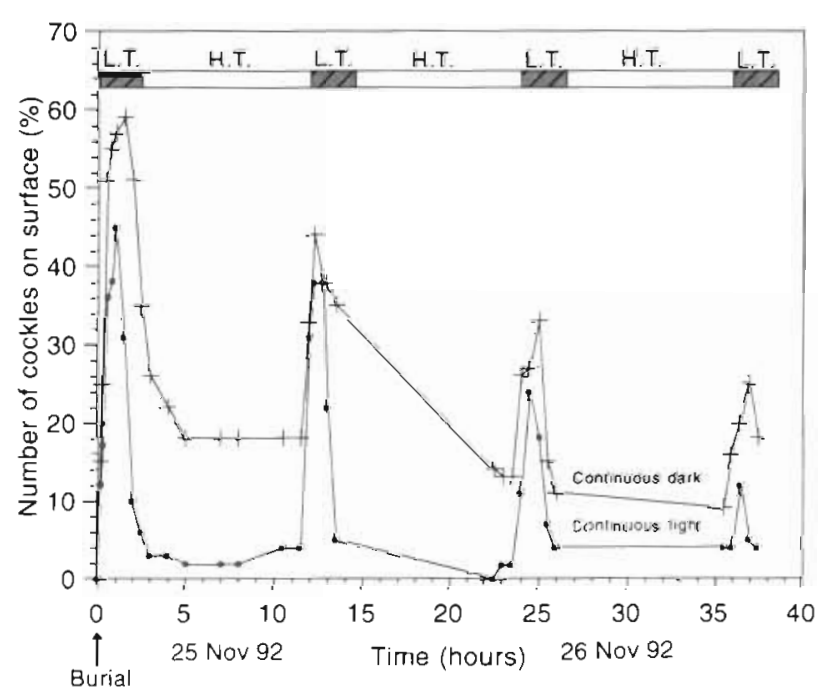

Fig. 4. Cerastoderma edule. A 2 d record of emergence behaviour of cockles in a simulated semidiurnal tidal regime in the laboratory. Two groups of cockles maintained in continuous darkness and continuous illumination were buried with a $2 \mathrm{~cm}$ covering of sediment prior to emersion. $\mathrm{HT}=$ high tide; $\mathrm{LT}=$ low tide 
adjacent individuals, as the nearest neighbour analysis shows. When there is a high cockle density there is greater probability of colliding with another individual, so interactions and activity are higher and sustained for much longer than at lower densities. Eventually, after $30 \mathrm{~d}$, the activity of the cockles became reduced and the population stabilised. An interesting question was whether the emergence rhythm could be induced once the cockles had settled down.

Twenty-two cockles (density ca $180 \mathrm{~m}^{-2}$ ) were placed in a tightly aggregated clump in the tidal tanks and their activity monitored for $12 \mathrm{~d}$. The activity of the cockle population changed from $41 \%$ on Day 1 to no activity on Day 12 . Twenty-two freshly collected cockles were labelled and introduced randomly onto the surface of the sand above the buried cockles. The activity of the cockles was once again monitored, but only the labelled cockles were active; none of the original buried cockles were induced to emerge. The experiment was repeated with 50 cockles (density ca $200 \mathrm{~m}^{-2}$ ) and similar results were obtained.

\section{Response of cockles to burial by sediment}

In all of the above experiments the emergence of the cockles at emersion during darkness and their continued movements during the initial immersion period indicates that darkness stimulates them to move. If the biological significance of this activity is to be elucidated, then it is necessary to consider which other naturally occurring events, other than changes in illumination, could stimulate the cockles to emerge and move. One event could be the smothering or burial of the cockles with sediment.

Two groups of 55 cockles of similar size $(25 \mathrm{~mm})$ were placed in 2 halves of the tidal tank under simulated semidiurnal tidal conditions and $12 \mathrm{~h}$ light : $12 \mathrm{~h}$ dark for $30 \mathrm{~d}$ until the emergence rhythm had all but ceased. One half of the tank was then continuously illuminated whilst the other was kept in continuous darkness. Simultaneously, a $2 \mathrm{~cm}$ covering of sediment was added just as the water was receding from the tank. Fig. 4 shows the activity pattern of the 2 groups of cockles. Immediately upon burial and emersion the cockles emerged onto the surface, $60 \%$ of the cockles appearing in continuous darkness and $45 \%$ in the continuously illuminated tank. The obvious difference between the 2 conditions was that during emersion in the light, the cockles appeared onto the surface and reburrowed almost immediately, disappearing beneath the sediment surface prior to and during high tide. In continuous darkness, however, the cockles emerged, remained on the surface during low tide, and then upon re-immersion crawled across the sediment surface. Some $20 \%$ of the cockles continued to remain active until the following emersion during darkness. This difference in activity in the 2 regimes continued for the ensuing 3 low tides with a gradual decline in activity.

\section{Field experiments}

Dispersion patterns and activity of cockles in the natural environment

Analysis of the distribution of cockles at 3 tidal levels at Traeth Melynog using the Fisher Coefficient of Dispersion showed that the dispersion coefficient was not significantly different from unity (Table 3), indicating that the cockles were randomly distributed.

In view of the results obtained when cockles were buried experimentally in the laboratory with sediment, a similar experiment was conducted on the shore at Traeth Melynog.

Our observations at various tidal levels on the shore, when large black plastic sheets were placed on the sand surface to simulate sudden darkness, and at the onset of darkness during the ebb tide, showed that cockles would not emerge naturally under these conditions. However, when cockles were smothered with sediment during the ebbing tide they did respond to burial. Fig. 5 shows the average number of cockles emerging onto the surface at mean tide level in three $1 \mathrm{~m}^{2}$ areas. Cockles began to appear on the surface about $1.5 \mathrm{~h}$ after the addition of sediment as the natural light began to fade, reaching a maximum during darkness. Some of the cockles moved around on the surface during darkness before reburial. Unfortunately, no observations could be made once the cockles were immersed by the flooding tide. The following night

Table 3. Cerastoderma edule. The distribution pattern of cockles at 3 tidal levels on the shore at Traeth Melynog, N. Wales, UK. Distribution pattern determined from the $\chi^{2}$ approximation to the Fisher Coefficient of Dispersion

\begin{tabular}{lccc}
$\begin{array}{l}\text { Approximate } \\
\text { tidal level }\end{array}$ & $\begin{array}{c}\text { Cockle } \\
\text { density } \\
\left(\mathrm{m}^{-2)}\right.\end{array}$ & $\begin{array}{c}\text { Coefficient of } \\
\text { Dispersion }\end{array}$ & $\begin{array}{c}\text { Distribution } \\
\text { pattern }\end{array}$ \\
\hline $\begin{array}{l}\text { High water of } \\
\text { neap tide }\end{array}$ & 33 & 1.198 & $\begin{array}{l}\text { Random } \\
\text { Rid tide level }\end{array}$ \\
29 & 1.012 & $\begin{array}{l}\text { Random } \\
\text { Random }\end{array}$ \\
& 56 & 1.371 & Random \\
Low water of & 222 & 1.130 & Random \\
neap tide & 228 & 1.134 & Random \\
\hline
\end{tabular}




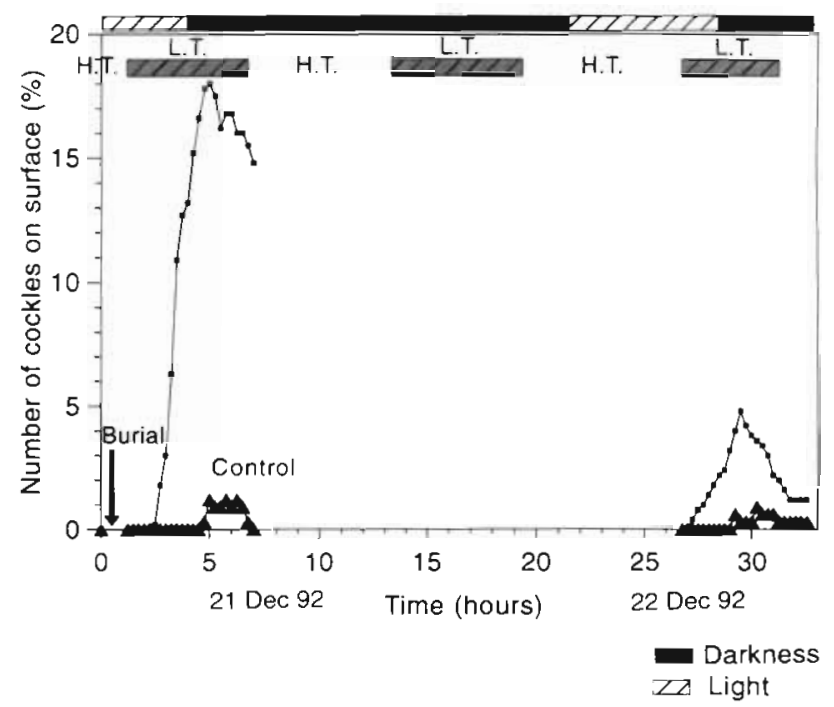

Fig. 5. Cerastoderma edule. A 34 h record of emergence behaviour of cockles on the shore at Traeth Melynog in the Menai Strait, N. Wales, UK. Undisturbed cockles were buried with a $2 \mathrm{~cm}$ covering of sediment during the ebb tide and the average number of cockles emerging onto the surface during daylight (hatched area) and darkness (filled area at top of figure) in 3 replicate $1 \mathrm{~m}^{2}$ areas recorded. For comparison, the average number of cockles emerging in undisturbed control areas is also shown. The cockles emerged during low tide with peak activity during darkness. HT = high tide; LT = low tide

there was emergence activity at emersion once again, although the activity was reduced. In contrast, only a few cockles in the control areas were observed to emerge during emersion, with their activity coinciding exactly with darkness (Fig. 5).

\section{DISCUSSION}

Cockles Cerastoderma edule are less active burrowers than other bivalves, such as razor clams Ensis siliqua and surf clams Donax serra (Morton 1964, Ansell \& Trueman 1973). However, cockles have been observed to leap when attacked by starfish (Morton 1964), creep along the sediment surface (Rygg 1970) and burrow into the substratum (Trueman et al. 1966, Breum 1970). According to Brock (1979), C. edule is a more active burrower than $C$. glaucum, allowing $C$. edule to colonize more unstable environments than its congener. C. glaucum for example, never occurs in areas where the sediment is unconsolidated, probably because it is unable to maintain its position by burrowing, nor can C. glaucum escape from the substratum following deposition of additional sediment during storms (Trueman 1983).

Cerastoderma edule is the dominant intertidal bivalve at Traeth Melynog where it can occur in densi- ties ranging from $27 \mathrm{~m}^{-2}$ on the high shore to $228 \mathrm{~m}^{-2}$ on the low shore (see Table 3 ). Similar densities have been recorded by Sutherland (1982) and SanchezSalazar et al. (1987) on the same shore.

The shore at Traeth Melynog has a southeasterly aspect and is protected from southerly and southwesterly gales by the sand dune complex of Newborough Warren (Sanchez-Salazar et al. 1987). The combined effects of waves and currents in the Menai Strait, however, particularly during storms and gales, may undermine the stability of the shore and result in its erosion, and deposition elsewhere. Cockles in particular may be vulnerable because of their surface dwelling habit. They occur in the top 2 to $5 \mathrm{~cm}$ of the substratum and although movements of sand may not be very great, the cockles still need to maintain contact with the sand surface through their short siphons. Should cockles become dislodged from the substratum, then their round globular shaped shells will make them vulnerable to being rolled around the shore by the flood and ebb tide (Morton 1964). Sutherland (1982) has speculated that there might be passive transport of cockles rolling down from the high shore at Traeth Melynog to supplement and maintain the number of settling cockles in the lower shore populations. Evidence for this is based on the observation that freshly uncovered cockles at the water's edge are rolled by the incoming flood tide. Such downshore passive movements have been suggested for Macoma balthica (Reading 1979). The active emergence, movement and reburrowing of cockles demonstrated in this study is a consequence of the cockles' mobility in response to tidal and daily environmental variables in order to maintain their position in an unstable sandy shore. The occurrence, on occasions, of large numbers of epifaunal cockles and the loss of experimental cages and wooden stakes on the lower part of the shore at Traeth Melynog reflects the unstable nature of the shore at this level. An exogenously driven activity rhythm which enables the cockles to disperse on the shore and reburrow when they have been disturbed may have important implications in the structuring of bivalve communities.

Dispersion patterns and active movements of some deposit feeding bivalves have been related to the maintenance of feeding territories (Holme 1950, Connell 1955, 1963, Johnson 1959, Levinton 1972, Wilson 1976, Wilson \& Shelley 1986). On a large scale (of several hundred $\mathrm{m}^{-2}$ ) the dispersion of bivalves will depend on the nature of the environment. If a bivalve species requires a specific sediment type or the environment is heterogeneous, then an aggregated dispersion pattern will result, since the optimum habitat for the animals will occur patchily (Hairstone 1959, Levinton 1972, Wilson 1976, Wilson \& Shelley 1986). In most 
situations, however, the observed uniform dispersion of bivalves can be explained in terms of competition for food (Heip 1975). Suspension feeding bivalves do not defend their territory, unlike deposit feeding species whose long siphons roam across the sediment surface and may interact with other individuals, resulting in a uniform dispersion (Holme 1950). The distribution of suspension feeders would therefore be expected to be random (Heip 1975, Wilson 1976). Different dispersion patterns of the same species have been observed in laboratory tanks and natural field situations (Wilson \& Shelley 1986). The explanation for the differences may be a question of scale, with high densities of animals in small laboratory aquaria held under different environmental conditions than those occurring naturally. The larger the area of study the more the dispersion pattern is a reflection of ecological variations and environmental heterogeneity. Therefore, interspecific and intraspecific interactions for food and space may only become apparent in small areas of study, such as laboratory tanks

The analysis of the dispersion patterns of cockles on the shore at Traeth Melynog by means of the Fisher's $x^{2}$ approximation was calculated in small areas $\left(0.2 \mathrm{~m}^{2}\right)$. On this scale, the resulting distribution would be a reflection of the interaction between cockles, since movements over small distances are very important, as shown in the laboratory experiments. In all the experiments there was a tendency for freshly collected cockles to move apart when they were placed in an aggregation, as shown by an increase in the nearest neighbour distance between cockles. In the experimental tanks cockles interacted and induced each other to appear on the sand surface and move randomly. This movement in turn affected the position of other cockles buried in the substratum. Thus, as the density of the cockles was increased, the nearest neighbour distance decreased with the probability of increased interactions between cockles. The appearance, movement and reburrowing activity of the cockles is therefore positively correlated with high densities or aggregated patterns. During the first weeks in the laboratory the cockles were observed to actively disperse over the area of the tank. At low densities, cockles form a random dispersion pattern, whilst at the higher densities they become uniformly distributed. An analysis of the dispersion patterns in both field and laboratory situations gave similar results when there was a low density in the laboratory. Only when the density of the cockles was increased did the differences between laboratory and natural environment become apparent.

The most important experiments in understanding the observed dispersion patterns and interaction between individual cockles in the laboratory were those in which the cockle density was doubled once the cockles had redistributed themselves and their emergence activity had disappeared. Here, only freshly collected marked cockles introduced into the tank showed the emergence rhythm and interactions between their neighbours. Those cockles whose rhythm had disappeared could not be induced to move. Thus, interactions and movements of cockles in the laboratory appear to be artefacts induced by disturbance of the cockles when they are collected from the natural sediment and transported to the laboratory. The effect of differences in sediment type between the Newborough sand in the laboratory and the natural sediment from Traeth Melynog might have contributed to the cockles' activity. However, when cockles were transplanted into natural sediment in the laboratory there was no difference in activity when compared with the Newborough sand

Naturally, cockles do not display emergence activity at Traeth Melynog. Neither the imposition of sudden darkness, when black plastic sheets were placed on the shore, nor the coincidence of darkness with low tide, was sufficient to stimulate the cockles to emerge. However, shortly after smothering the natural cockle population with sediment, there was a period of emergence activity during low tide. Disturbance during collection and the sudden change in illumination and darkness in the laboratory did induce the emergence behaviour pattern in cockles. This activity was further enhanced when sediment was added during low tide. The emergence rhythm will therefore occur naturally, but in response to the stimulus of covering and darkening by sediment during sporadic storm-induced burial. Our observations that cockles are found living epifaunally at Traeth Melynog, and the occasional occurrence of cockle tracks (furrows) on the shore, further supports our findings that this type of locomotory behaviour exists naturally. Orton (1926) and Kreger (1940) both describe the existence of cockle furrows on mud flats at Southend-on-Sea (SE England) and in the Dutch Wadden Sea respectively. Indeed, dark-induced emergence rhythms may be quite common. Rygg (1970), for example, found that the creeping activity of Cerastoderma edule was greater in the laboratory during periods of darkness than during light conditions. Quayle (1949) similarly observed active movements of the clam Tapes pullastra in the laboratory during the first night of darkness. Neither of these workers investigated these observations further. Cockles have relatively well-developed eyes in the sensory tentacles on the rim of the inhalent and exhalent siphons (Charles 1966). Thus, it is likely that cockles will be able to detect and react to natural fluctuations in illumination such as those associated with the sudden deposition of sediment during storms. 
The laboratory situation is clearly different from the natural condition, as the cockles were disturbed during collection and transportation and transferred to a laboratory tank with an unnatural light regime, with abrupt arrival of darkness and light. However, the laboratory experiments did show that the cockles were able to detect and react to changes in illumination. The cockles' eyes thus may be important in detecting visual cues. Indeed, in the continuously illuminated tank, cockles which had become smothered with sediment reburied on reaching the surface, whereas in continuous darkness cockles remained on the surface during low tide, roaming across the surface upon immersion and then reburying. The development of eyes in bivalves may have evolved for the immediate detection of factors affecting the animals position in the sediment, such as the presence of predators or burial by sediment. The presence of a predator will induce a typical shadow response, whilst the sudden onset of darkness induces the cockles to emerge and move over the sediment surface. The sudden arrival of darkness in the laboratory experiments simulated deposition of sediment in the field and induced the cockles to move and maintain contact with the surface of the sediment. As the observed emergence and movement of Cerastoderma edule involves the same mechanism described for typical burrowing behaviour (Trueman et al. 1966, Trueman 1983) nocturnal emergence and ploughing activity described in this study, we believe, represents a situation in which the cockles are trying to emerge from the sediment just as if they were covered with sediment. Once emerged, there will be considerable advantage to the cockles to either crawl over the surface or to be rolled away from the disturbance by the incoming tide. Ansell \& Trueman (1973) have suggested that migration of the surf clam Donax serra away from the surf zone would be more profitable than having to continually emerge and reburrow in shifting sediment. This would apply equally to cockles buried by sediment.

The disadvantage of emerging onto the surface would be that the cockles would be vulnerable to predators. Oystercatchers, for example, feed actively on Cerastoderma edule on the upper part of the shore at Traeth Melynog (Sutherland 1982). Although less efficient, oystercatchers still feed on cockles during the night using tactile foraging (Evans 1988). Active predators such as foraging crabs Carcinus maenas feed extensively at high tide on the cockle population at Traeth Melynog (Sanchez-Salazar et al. 1987). The display of an emergence rhythm on the shore could therefore be very disadvantageous. However, the benefit of emerging after sediment burial may outweigh the risk of being eaten by predators.
Acknowledgements. We are grateful to Prof. E. Naylor, Drs R. Seed and C. G. Warman for critically commenting on an early draft of this manuscript and for stimulating discussions during the course of the work. I.I. is grateful for financial support from the Spanish Government and C.A.R. is grateful to the NERC for a Personal Research Fellowship (GR3/7390'A'). The comments of an anonymous referee helped considerably in improving this paper.

\section{LITERATURE CITED}

Ansell, A. D. (1968). Defensive adaptations to predation in the Mollusca. Proc. Symp. Moll., Part II. Marine Biological Assocation of India, Mandapam Camp, p. 38-39

Ansell, A. D., Trevallion, A. (1969). Behavioural adaptations of intertidal molluscs from a tropical sandy beach. J. exp. mar. Biol. Ecol. 4: 9-35

Ansell, A. D., Trueman, E. R. (1973). The energy cost of migration of the bivalve Donax on tropical sandy beaches. Mar. Behav. Physiol. 2: 21-32

Breum, O. (1970). Stimulation of burrowing activity by wave action in some marine bivalves. Ophelia 8: 197-207

Brock, V. (1979). Habitat selection of two congeneric bivalves, Cardium edule and C.glaucum in sympatric and allopatric populations. Mar. Biol. 54: 149-156

Brown, A. C. (1983). The ecophysiology of sandy beach animals - a partial review. In: McLachlan, A., Erasmus, T. (eds.) Sandy beaches as ecosystems. W. Junk, The Hague, p. 575-605

Charles, G. H. (1966). Sense organs (less cephalopods). in: Wilbur, K. M., Yonge, C. M. (eds.) Physiology of Mollusca, Vol. II. Academic Press, New York, p. 455-521

Clark, P. J., Evans, P. C. (1954). Distance to nearest neighbour as a measure of spatial relationships in populations. Ecology $35: 445-453$

Clark, R. B., Milne, A. (1955). The sublittoral fauna of two sandy bays on the Isle of Cumbrae, Firth of Clyde. J. mar. biol. Ass. UK. 34: 161-180

Connell, J. H. (1955). Spatial distribution of two species of clams, Mya arenaria L. and Petricola pholadiformis Lamark, in an intertidal area. Rep. Fish. Inv. Mass. 8: $15-25$

Connell, J. H. (1963). Territorial behaviour and dispersion in some marine invertebrates. Res. Popul. Ecol. 5: 87-101

Evans, P. R. (1988). Predation of intertidal fauna by shorebirds in relation to time of the day, tide and year. In: Chelazzi, G., Vannini, M. (eds.) Behavioural adaptations to intertidal life. NATO ASI Series, 15, New York and London, p. $65-78$

Hairstone, N. G. (1959). Species abundance and community organisation. Ecology 40: 404-416

Heip, C. (1975). On the significance of aggregation in some benthic marine invertebrates. In Barnes, H. (ed.) Proc. 9th Eur. Mar. Biol. Symp. Aberdeen Univ. Press, Aberdeen, p. $527-538$

Holme, N. A. (1950). Population dispersion in Tellina tenuis da Costa. J. mar. biol. Ass. U.K. 29: 267-280

Hulscher, J. B. (1973). Burying-depth and trematode infection in Macoma balthica. Neth. J. Sea Res. 6: 141-156

Johnson, R. G. (1959). Spatial distribution of Phoronopsis viridis. Science 129: 1321

Kreger, D. (1940). On the ecology of Cardium edule L. Archs néerl. Zool. 4: 157-200

Levinton, J. (1972). Spatial distribution of Nucula proxima Say (Protobranchia): an experimental approach. Biol. Bull. 143: $175-183$ 
McLachlan, A. (1988). Behavioural adaptations of sandy beach organisms: an ecological perspective. In: Chelazzi G., Vannini, M. (eds.) Behavioural adaptations to intertidal life. NATO ASI Series 151, New York and London, p. $449-475$

McLachlan, A., Young, N. (1982). Effects of low temperature on the burrowing rates of four sandy beach molluscs. J. exp. mar. Biol. Ecol. 65: 275-284

Morton, J. E. (1964). Locomotion. In: Wilbur K. M., Yonge, C. M. (eds.) Physiology of Mollusca, Vol. I. Academic Press, New York, p. 383-423

Orton, J. H. (1926). On the rate of growth of Cardium edule. Part 1, Experimental observations. J. mar. biol. Ass. U.K 14: $239-280$

Quayle, D. B. (1949). Movements in Venerupis (Paphia) pullastra (Montagu). Proc. Malac. Soc. Lond. 28: 31-37

Reading, C. J. (1979). Changes in downshore distribution of Macoma balthica (L.) in relation to shell length. Estuar coast. mar. Sci. 8: 1-13

Rygg, B. (1970). Studies on Cerastoderma edule (L.) and Cerastoderma glaucum (Poiret). Sarsia 43: 65-80

Sanchez-Salazar, M. E., Griffiths, C. L., Seed, R. (1987). The interactive role of predation and tidal elevation in structuring populations of the edible cockle, Cerastoderma

This article was submitted to the editor edule. Estuar. coast. Shelf. Sci. 25: 245-260

Stanley, S. M. (1970). Relation of shell form to life habits of the Bivalvia (Mollusca). Geol. Soc. Am. Mem. 125: 1-296

Stanley, S. M. (1987). Adaptive morphology of the shell in bivalves and gastropods. In: Trueman, E. R., Clarke, M. R (eds.) The Mollusca, Vol. 11. Academic Press, New York, p. 105-142

Sutherland, W. J. (1982). Spatial variation in the predation of cockles by oystercatchers at Traeth Melynog, Anglesey. I. The cockle population. J. Anim. Ecol. 51: 481-489

Swennen, C. (1969). Crawling tracks of trematode infected Macoma balthica (L.). Neth. J. Sea Res. 73: 376-379

Trueman, E. R. (1983). Locomotion in molluscs. In: Saleuddin, A. S. M., Wilbur, K. M. (eds.) The Mollusca, Vol. 4. Academic Press, New York, p. 155-198

Trueman, E. R., Brand, A. R., Davis, P. (1966). The effect of the substrate and shell shape on the burrowing of some common bivalves. Proc. Malac. Soc. Lond. 37: 97-109

Wilson, J. G. (1976). Dispersion of Tellina tenuis from Kames Bay, Millport, Scotland. Mar. Biol. 37: 371-376

Wilson, J. G., Shelley, C. (1986). The distribution of Nucula turgida (Bivalvia: Protobranchia) from Dublin Bay, Ireland, and the effect of sediment organic content. J. mar. biol. Ass. U.K. 66: 119-130

Manuscript first received: April 7, 1992

Revised version accepted: June 16, 1993 